\author{
Andrzej Sobczak \\ Warsaw School of Economics \\ e-mail: sobczak@sgh.waw.pl \\ ORCID: 0000-0002-1271-1251
}

\title{
DEVELOPING A ROBOTIC PROCESS AUTOMATION MANAGEMENT MODEL
}

\section{BUDOWA MODELU ZARZĄDZANIA ROBOTYZACJĄ PROCESÓW BIZNESOWYCH}

\author{
DOI: $10.15611 /$ ie.2019.2.06 \\ JEL Classification: L86, O33
}

\begin{abstract}
Summary: One of the distinguishing features of digital transformation is the large scale business process automation, and, in particular, robotic process automation - with the use of software from the currently growing RPA (Robotic Process Automation) category. This is such a new field that a commonly accepted conceptual apparatus (terminology) has not been developed yet, also methodical tools for effective robotic process automation management are missing. Based on the above observations it was deemed justified to conduct research aimed at: (G1): developing a "robotic process automation" definition proposal, (G2): identifying the key "robotic process automation" management aspects in Polish medium and large enterprises; (G3): developing a robotic process automation management model structure and completing its initial verification. The outcome of the research conducted is the development of a proprietary robotic process automation management model structure that was initially verified at one of companies.
\end{abstract}

Keywords: robotic process automation, business process, hybrid work environment.

Streszczenie: Jedynym z wyróżników cyfrowej transformacji jest masowa automatyzacja procesów biznesowych, a szczególnie ich robotyzacja - z wykorzystaniem narzędzi informatycznych zaliczanych do rozwijającej się obecnie kategorii RPA (Robotic Process Automation). Jest to obszar na tyle nowy, że nie ukształtował się jeszcze powszechnie obowiązujący aparat pojęciowy, brakuje także narzędzi metodycznych do efektywnego zarządzania robotyzacją procesów. Ze względu na powyższe obserwacje uznano, że uzasadnione jest przeprowadzenie badań, których celem jest: (C1): stworzenie propozycji definicji terminu „robotyzacja procesów biznesowych", (C2): zidentyfikowanie kluczowych aspektów zarządzania robotyzacją procesów biznesowych w polskich przedsiębiorstwach - średnich i dużych; (C3): opracowanie struktury modelu zarządzania robotyzacją procesów i jego wstępna weryfikacja. Efektem przeprowadzonych badań jest opracowanie autorskiej struktury modelu zarządzania robotyzacją procesów biznesowych, która została wstępnie zweryfikowana.

Słowa kluczowe: robotyzacja procesów biznesowych, procesy biznesowe, hybrydowe środowisko pracy. 


\section{Introduction}

Currently, as a consequence of the widespread use of information technology, a transformation of the functioning of both individual entities as well as entire industries can be observed (Berman, 2012, p. 16; Nylén \& Holmström, 2015, p. 57). The changes underway are called digital transformation. This encompasses transforming organizations' business models, their products and processes, as well as organizational structures (Reis, Amorim, Melão, \& Matos, 2018, p. 411).

One of the distinguishing features of digital transformation is large scale business process automation, and in particular robotic process automation ${ }^{1}$ - with the use of software from the currently very fast growing RPA (Robotic Process Automation) category (Willcocks \& Lacity, 2016, pp. 65-66). This is such a new field that a commonly accepted conceptual apparatus (terminology) has not been developed yet, also methodical tools for the effective implementation of robotic process automation are not as yet available.

Based on the above observations it was deemed justified to conduct and present the results of research - both literature based, as well as empirical - aimed at:

- (G1): developing a 'robotic process automation' definition proposal;

- (G2): identifying the key 'robotic process automation' management aspects;

- (G3): developing a robotic process automation management model structure and completing its initial verification.

To accomplish goal (G1), an analysis of literature ${ }^{2}$ was completed. The focus was primarily on English language publications - the books and articles in the

${ }^{1}$ It should be emphasized that robotic process automation is not identical with the robotic automation of industrial processes implemented by manufacturing companies. They represent different thematic scopes - both in terms of their subject matter, as well the IT tools applied.

2 The starting point for selecting publications referenced to in the article was the analysis of items, completed in August 2019, stored in the Web of Science (WoS) Core Collection. After entering the phrase 'Robotic Process Automation' into the WoS search engine (searches were conducted on titles of materials, abstract and key words), 23 items were found (search criteria were narrowed down to English language sources). Each of them was initially analyzed. Five included contents totally irrelevant to the issues discussed in the article, another seven included imitative content, while others were found to be relevant and they were taken into account in the analysis conducted. Subsequently (also in August 2019), a similar analysis was conducted using the SCOPUS database (items containing the phrase 'Robotic Process Automation' were searched for on both titles, as well as key words); 56 items were found in total. Each of them was initially analyzed and nine items included contents totally irrelevant to the issues discussed in the article, 14 items were overlaps of items deemed relevant following the WoS analysis, further 19 items contained imitative content, while others were found to be relevant and they were taken into account in the analysis conducted. In the final stage, the analysis of books on robotic process automation was conducted. Based on the criteria of relevance with the issues covered in the article, the currency of the content presented and the methodology apparatus used, the decision was taken to include five of them in the literature research. However, the author is aware of the limitations of the adopted research procedure that in its current form cannot be called a systematic literature review (Mazur \&Orłowska, 2018, p. 236 and further on). 
reviewed publications. A conscious decision was made to reference reports prepared by consulting companies to a limited extent due to the relatively low scientific rigor applied in compiling such documents. To accomplish goal (G2), the results of partly structured interviews, that the author had conducted with the representatives of selected companies, were used. To accomplish goal (G3), creative thinking techniques, literature analysis and case study analysis were used.

The article, due to its set goals, has the following structure. Based on the results of the study, the robotic process automation concept was defined in its second part in two ways: narrowly (solely technology based), and more broadly - management and technology based. The third part of the article presents, identified based on partly structured interviews, the key robotic process automation management aspects. The proprietary robotic process automation management model structure is presented and its initial verification is discussed in the two subsequent parts. The article concludes with the summary and discussion of further research directions.

\section{Robotic process automation - definition attempt}

The subject matter literature most frequently identifies the term 'robotic process automation' with the Robotic Process Automation (RPA) class of software, currently growing fast on the IT market ${ }^{3}$ and a part of the broader Business Process Automation (BPA) tools category.

Despite the fact that the Robotic Process Automation concept surfaced for the first time on the market in 2012 (Fersht \& Slaby, 2012), it should be noted, however, that no single commonly applicable definition of this class of tools has been developed up to now. Based on the studies of literature (Aguirre \& Rodriguez, 2017; Asatiani \& Penttinen, 2016; Lacity \& Willcocks, 2016; Willcocks \& Lacity, 2016), the author made an attempt to identify its distinguishing features. It may be assumed that an RPA tool enables developing software robots using graphical wizards (or alternatively, by recording actions performed by a human-operator), that:

- operate based on the preset algorithm, but more and more often are enriched with certain elements of artificial intelligence, and, as a result, are able to take more complex decisions (in particular, they are able to learn based on the data provided - both structured, as well as unstructured);

- automate large scale (mass) operations (i.e. performed multiple times within the assumed time unit - e.g. within a month or a year), carried out by an operator up to now, most often by faithfully reproducing them;

\footnotetext{
${ }^{3}$ Confirmation of the very fast growth rate of this part of the IT market can be the results of analyses according to which the global value of the RPA tools market was estimated to stand at USD 849 million in 2018, while in 2019 even USD 1.3 billion., while in 2021 as much as USD 2.9 billion (Clair Cullen \& King, 2017).
} 
- perform operations directly on a graphical user interface of IT systems - the same way as a human-operator does it (although some RPA tools allow performing operations directly on the data layer);

- use the business logic that constitutes an integral part of the applications with which a software robot will be working, which eliminates the problem of reproducing such logic that occurs in the traditional systems integration or development models.

RPA tools are used primarily with respect to operational processes and business support processes, they are implemented less often in the direct customer service area (Chatbots/Voicebots are commonly used here).

It is also worth noting that RPA tools are usually not used to robotically automate processes end-to-end but most frequently for selected sub-processes of the given process or even process building blocks (elements).

The final distinguishing feature of RPA tools is vendors seeking to make them so intuitive to operate that representatives of business units could operate them on their own (so that they could create software robots themselves without support or with minimum support of IT departments).

The above considerations focus on the understanding of the term 'robotic process automation' as a specific class of software with a certain set of features. At the same time, one may, more and more often, come across a different interpretation of this term. According to this interpretation 'robotic process automation' is viewed more broadly (Fersht, Gupta, \& Christopher, 2019) as a particular type of an organizational and technological change (an inherent part of which is the implementation of specific software) leading to the appearance of the so-called hybrid work environment. This environment is understood as a coherent set of IT tools (business applications and software robots), processes and procedures, as well as people with certain competences and skills, carrying out specific business processes and processing specific data.

For the purpose of this article the latter, broader understanding of the robotic process automation concept is assumed.

\section{Key aspects of robotic process automation management}

In 2018-2019 the author conducted an analysis of 14 projects completed in Poland, related to the implementation of RPA tools in medium and large companies representing diverse industries (banking, insurance, telecommunications, financial services, BPO (Business Process Outsourcing) and SSC (Shared Service Center), e-commerce, traditional retail). However, the author is aware of the fact that a 14-interview sample is limited in size. The reason for such limited size was still the low penetration of robotic process automation. The analysis was based on semistructured interviews conducted with persons in charge of robotic process automation implementations (middle level management personnel) or supervising such 
implementations (higher level management personnel). The criterion for selecting respondents was having completed at least one pilot RPA tool implementation. The interviews were carried out using the CAPI (Computer Assisted Personal Interview) technique, in the October 2018-July 2019 time frame. The research constituted a continuation of the research conducted by the author between March and September 2018.

As indicated by the interviews, robotic automation was in many companies viewed, in the beginning as an ad-hoc activity that was supposed to be a response to the ongoing problems faced by the organization. Frequently, the development of software robots was also regarded as a certain type of experiment. Only after the first two to three robots had been implemented it turned out that robotic automation should be viewed as a complex, multifaceted undertaking that should be managed appropriately in order to achieve the expected benefits.

Based on the interviews conducted, eight key aspects of robotic process automation management were identified (those that repeated most often during the above mentioned interviews were assumed to be the key ones and they were the subject of the main attention of the respondents).

\subsection{Conditions and goals of implementing robotic process automation}

As mentioned in the introduction, the term Robotic Process Automation was used for the first time in the paper prepared by the analytical company HfS Research in 2012 (Fersht \& Slaby, 2012). RPA tools gained large-scale popularity (measured, among others, by market size) worldwide around 2017-2018. This is confirmed by the research of a number of advisory and consulting companies indicating that the global value of the RPA tools market in 2018 was estimated to stand at USD 849 million, while in 2019 even USD 1.3 billion (Gartner, 2019), and in 2021 as much as USD 2.9 billion (Clair, Cullen, \& King 2017). This was a consequence of a number of factors - visible worldwide, but also important from the point of view of Polish enterprises. They include:

- progressing digitization of business processes, leading to data storage in electronic form,

- constant pressure on improving earnings of an organization and looking for quick methods to achieve such results,

- low efficiency of internal IT departments that are not able to meet the expectations of business divisions within specific time and budget,

- seeking to improve the customer experience, facilitated through large digital transformation programs that focus on the so-called Front Office, and, to a small extent, encompass support processes implemented in the Back Office,

- growing technology debt (defined as any approach taken - consciously or not during an IT system deployment that will hinder its future development/further changes), occurring in a number of organizations, leading de facto to the 
disintegration of the IT environments of such entities. As indicated by the author's observations, in a number of Polish enterprises, instead of integration based on services, API or other solutions, a human-operator is introduced in their place, performing the role of a "human interface".

Additionally, in reference to Poland, recent years have featured:

- material increase of labour costs incurred by employers - up to now Polish enterprises have usually competed on the global market not on innovations of products or services provided, but first of all on their price - see: GUS (Central Statistics) data (Główny Urząd Statystyczny [GUS], n. d.);

- constraints in availability of workforce of production age - with this trend increasing (see: Instytut Analiz Rynku Pracy, 2018);

- changing attitudes of young people entering the labour market - their value system and expectations towards the nature of their job are completely different than those of the X or even Y generations (the so-called Millenials) (see: Atermia, 2018).

With such ramifications in mind it is extremely important to define a set of the strategic goals of robotic process automation. As indicated by the interviews conducted by the author, for most of companies (except for one) the main goal of robotic process automation was to generate savings due to limiting the involvement of human resources in the implementation of business processes or to increase business processes performance capability without raising the headcount. At the same time, one should be aware of the fact that the implementation of the RPA tools may also have other goals - such as for example:

- improving employee experience by releasing personnel from performing the most mundane, routine activities,

- improving quality of the products/services provided - thanks to minimizing the number of errors in business processes implemented,

- increasing the organization's innovations - by providing the ability to quickly prototype new products/services that require an integration of various systems - without the need to engage IT departments.

\subsection{Risks related to robotic process automation}

Implementing robotic process automation involves not only a number of benefits, but also - as with any change - can be a source of risk for a company. As demonstrated by the analysis of almost 20 projects in this area conducted by the author, the most important risks may include:

- selecting the wrong business processes for robotic process automation - it turns out that preliminary estimates related to savings to be achieved thanks to robots may be unrealized, as the given process implementation in the given time interval may have been overestimated or the process has not been appropriately prepared for robotic process automation (no process standardization/optimization). 
- loss of knowledge of a robotically automated process - once personnel has stopped to perform a process manually, within 6-12 months the organization suffers an "amnesia" on how the given process is implemented,

- frequent changes to applications robots are working on - any change of the given application may potentially be a source of changes to a robot or robots working with the given application,

- problems with an IT tool selected to develop robots - it turns out that the RPA tools, despite their continuous evolution, still have a number of imperfections, due to their relatively short presence on the market,

- problems with ensuring appropriate security level for robotically automated applications - it should be realized that a robot accumulates the rights of a number of employees,

- lack of accurate knowledge among management personnel and field workforce on robotic process automation- often due to the perception of robots through the prism of images created in popular culture.

\subsection{Methods of acquiring robots for an organization}

Currently a number of methods of acquiring robots for an organization are available:

- Renting a robot - the so-called Robot-as-a-Service. A robot vendor (an external IT company) undertakes to analyze the process to be the subject of robotic automation, and then deals with developing and testing the robot, as well as its maintenance and potential evolution. In this approach, the provision of the entire IT infrastructure required for the functioning of robots is usually on the vendor's side. The customer settles accounts with the vendor in one of several variants:

- pays a fixed amount lump sum,

- pays for the actual robot work time (e.g. counted in minutes per month),

- pays for the number of transactions performed by the robot,

- pays a "success fee" for the result achieved, calculated based on the savings generated by the robot.

- Commissioning a robot development. A robot vendor (an external IT company) undertakes to analyze the process to be the subject of robotic automation, and then deals with developing and testing the robot. However, it is the customer who takes on the robot's maintenance and provides the IT infrastructure required for the functioning of robots. The customer settles accounts with the vendor usually in the form of a fixed amount, agreed upon at the beginning of the works;

- Developing a robot using internal (in-house) resources. A dedicated unit operating within the company, is usually the supplier of robots. However, this unit can be:

- part of the IT department,

- part of one of the business divisions,

- dedicated organizational unit - the so-called Center of Excellence dealing with robotic process automation. 


\subsection{Organizations' robot maintenance methods}

Individual organizations today use various models of maintaining robots already implemented in the organization:

- robot maintenance is carried out by an external provider - most often (but not always) by the company that has developed the given robot;

- robot maintenance is carried out by the internal IT department - however, this department did not have to be the developer of such robots. In this variant robot maintenance can be centralized within a single IT unit or distributed among various IT teams;

- robot maintenance is carried out by the Center of Excellence dealing with robotic process automation.

\subsection{Approach to standardizing the developed robots}

One of the main advantages of implementing robotic process automation - raised in the interviews - is the relatively short time it takes to develop robots (frequently measured in weeks, and not months, as happens in the case of traditional applications). In practice, this means, however, that an organization decides to develop a very simplified (frequently unsystematized) documentation of both robotically automated processes, as well as the robot code itself. Furthermore, in such cases the robot code is usually highly imperfect and requires, at a later stage (when introducing changes to the robot), refactoring (understood as a set of actions as a result of which the functionality of the modified software does not change but the technology debt is minimized), and in extreme cases, it is rewritten from scratch. This is why it extremely important to define, at the beginning of the robotic automation's implementation, what the expected standardization degree of individual works is. At the same time, one should be aware of the implications of standardization - the greater it is, the higher the cost and the longer the robot development time, however such a robot is not burdened with the "technological debt" and it is easier to make alterations to it.

The following are the most important areas that can be subject to standardization:

- documentation of robotically automated processes (e.g. whether a video showing the implementation of a business process is sufficient or it needs to be the documentation created using a formal notation - e.g. BPMN),

- documentation of a robot code (e.g. whether and how one documents the implementation algorithms applied),

- use of technology for robotic process automation (e.g. whether the company allows for applying tools provided by two or more RPA tool vendors). 


\subsection{Developing knowledge and communicating robotic process automation within an organization}

Robotic process automation is a new development in Polish companies. In practice this means that it is necessary to improve knowledge on this topic within organizations (both among the field workforce, as well as management). Additionally, it is important to develop and implement appropriate communications strategy in this respect. The main goals of communications include minimizing potential concerns among the workforce regarding implementing robotic process automation in the company and providing personnel with credible information on the RPA tools' capabilities and limitations.

\subsection{Interaction with the external environment}

The use of robotic process automation on a broader scale (implementing more than a few robots) is possible only when the close interaction of four groups of organizational units is put in place:

- a unit or units responsible for developing and maintaining robots (in particular it could be the above mentioned Robotic Process Automation Center of Excellence),

- business departments that are beneficiaries of the software robots implemented,

- IT department responsible for developing and maintaining the applications used as part of robotically automated processes,

- department responsible for security (IT security in particular).

In the case of entities operating in highly regulated industries (i.e. banking and insurance), an additional but very important stakeholder in the robotic automation process is the compliance department.

\subsection{Cost aspects of robotic process automation in an organization}

Gartner introduced the TCO (Total Cost of Ownership) concept in the mid-1990s, meaning the total cost of ownership and use of specific IT resources. TCO includes the total cost of acquiring, installing, using, maintaining and finally disposing of IT solutions within a certain period of time. TCA (Total Cost of Automation) is based on the same concept - the total cost of business automation. It presents, in a systematic way, the costs of automation (robotic automation in particular) of an organization's business processes and maintaining such automation. TCA includes direct costs, indirect costs and opportunity costs.

Direct costs include:

- robotic automation software - licences for an environment to develop robots and manage them, robot performance monitoring in particular, auxiliary software (e.g. robot code versioning tools); 
- robots - costs of developing robots (developing and testing a robot's code) and updating them (note: depending on the final way to approach robotic process automation such costs could be included in the personnel costs);

- hardware - servers on which robots will be deployed (currently these are, practically with no exception, virtualized environments);

- human resources - a team dealing with robot monitoring and maintenance (both the remuneration of such personnel, as well as the costs of their training should be included).

Indirect costs include:

- costs of synchronizing and overseeing the robots-IT department interaction costs of consulting and coordinating activities on the interface between robot development and the IT department maintaining the systems on which such robots are deployed;

- costs of communications within an organization - costs of communications activities directed towards personnel, aimed at appropriately presenting the robotic automation concept and building awareness of the personnel;

- costs of re-allocation/retraining of personnel - in some organizations robotic process automation will involve staff redundancies or transfers to other places within the organization;

- costs of downtime due to robot unavailability - costs of an interruption of operations (including costs of time lost by the personnel that utilizes the effects of robots' work). Some experts include here also the loss of reputation, customer resignations, loss of business opportunities, etc.

Opportunity costs include:

- cost of lost revenue - total loss of potential and actual revenue (under agreements) due to robot failures.

\section{Proprietary robotic process automation management model structure}

As already mentioned in the first part of the article, robotic process automation should be viewed as a complex, multifaceted undertaking that needs to be appropriately managed. However, methodical tools in this area are missing in the subject matter literature.

In order to at least partly minimize the identified gap the author has proposed a robotic process automation management model structure. Its development was based on:

- studies in the field of robotic process automation and the implementation of undertakings of transformational nature, conducted by the author (see the description of the manner the literature analysis was conducted in section two of the article); 
- expert interviews on robotic process automation conducted by the author, presented in the first part of the article;

- author's own experiences in implementing projects related to robotic process automation.

As part of carrying out the research the author:

- identified elements (building blocks) of the robotic process automation management model and prepared a brief description thereof;

- designed a graphic form of the robotic process automation management model structure.

As elements (building blocks) of the robotic process automation management model the author listed (their names are succinct on purpose in order to facilitate their subsequent presentation in a graphic form):

1. RPA goals - a summary of conditions that an organization is seeking to achieve by implementing robotic process automation. Such goals should have specific measures, as well as baseline and target values. The goals of robotic automation should be aligned with the business goals of an enterprise.

2. RPA acquisition - indicating how an organization is planning to acquire robots - using external or internal resources, and who is responsible for this task. In particular, it should be defined whether only one way is possible or if two or more ways to acquire robots are allowed.

3. RPA maintenance - indicating how an organization is planning to maintain robots - using external or internal resources, and who is responsible for this task.

4. RPA external environment - a summary of the company's internal and external units with a key impact on robotic process automation. These include: IT department (provided robotic automation is conducted by a unit positioned outside IT), security department, RPA technology (platform) vendor, advisory company supporting implementation of robotic process automation, etc.

5. RPA technologies - indicating what tools will be used to develop robots particularly specifying whether an organization uses a single RPA software or there could be more of them. It should also be outlined whether an organization is planning to use other solutions supporting robotic process automation - e.g. for robot source code versioning, robot performance monitoring, etc.

6. RPA standardization - indicating whether and in what areas an organization is planning to implement robotic process automation standards (e.g. in the process documentation, robot code development areas, etc.).

7. RPA knowledge and communications in an organization - a summary of actions/methods aimed at increasing the organization's knowledge of robotic automation and ensuring appropriate communications with managers and operational personnel with respect to robotic process automation.

8. RPA limitations - a summary of key factors that narrow down possible approaches to robotic process automation in the given organization to a shorter list of options. Such limitations can be due to industry specifics (e.g. as a consequence 
of the given entity operating in a tightly regulated industry - such as banking) or corporate conditions (this is particularly applicable to global companies and their Polish branches).

9. RPA risks - a list of key risk factors whose materialization may have a negative impact on the robotic automation project (in the financial, organizational or technological layer). Each risk should have a specific owner and proposed mitigation measures.

10. RPA cost aspects - a summary of key cost categories related to robotic process automation, broken down into technology costs (including license acquisition and maintenance costs), as well as organizational and personnel costs (e.g. training costs).

In developing a graphical form of the robotic process automation management model structure (see Figure 1) the author made a conscious reference to Alex Osterwalder's Business Model Canvas visualization (Osterwalder \& Pigneur, 2010). The goal was to achieve three benefits:

- make a reference to the commonly known and appreciated by business practitioners business model canvas concept,

- place the robotic process automation management model in the stream of management discussions and not those on technology,

- facilitate robotic process automation management model communications.

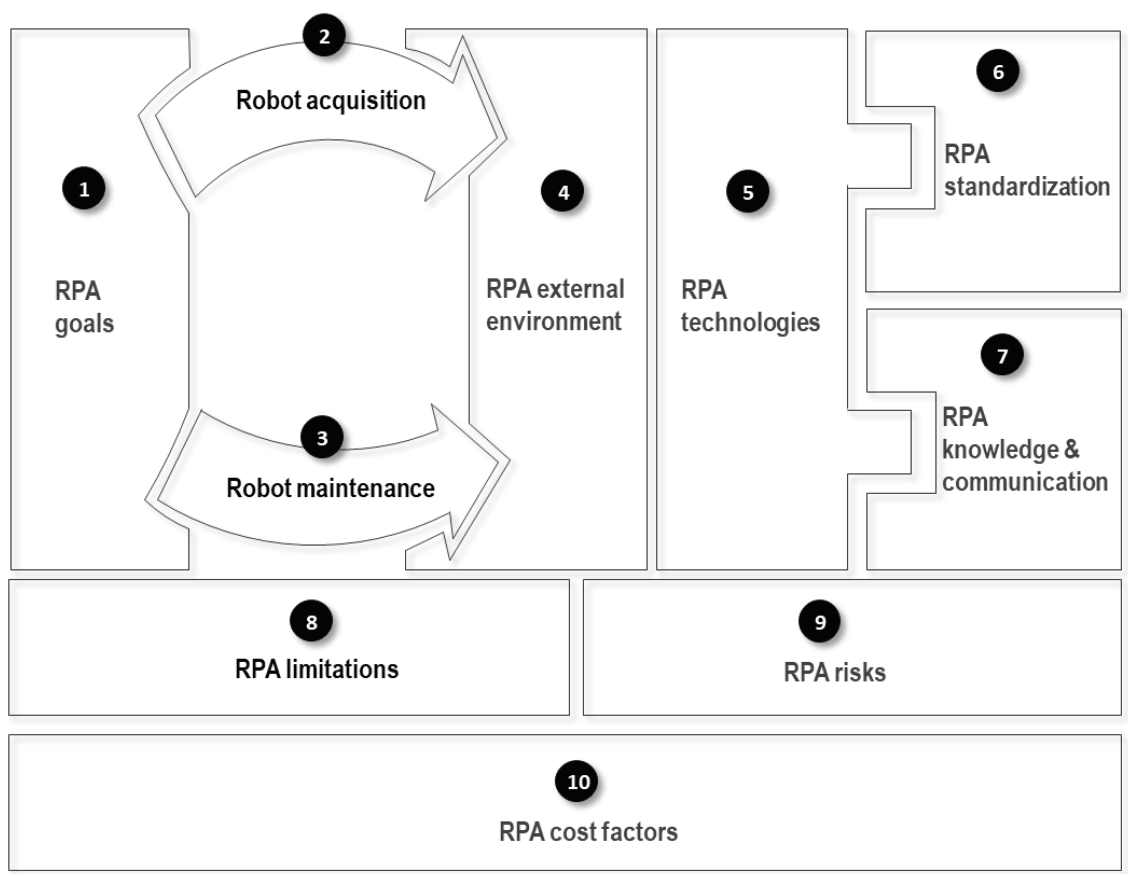

Fig. 1. Graphical form of the structure of robotic process automation management model Source: own compilation. 
At the current stage of research the author has not defined the recommended sequence of completing individual elements of the model, except for the first one: defining robotic automation goals. The approach to be pursued depends on the specifics of the given organization and availability of certain information/human resources required to prepare the model.

\section{Initial verification of the robotic process automation management model structure}

The robotic process automation management model structure discussed in Section 4 of the article has been initially verified by the author in one of companies operating in Poland. Its head office is located in Warsaw, but the company's scope of operations covers the entire country, with its products being offered primarily on the consumer market. The company operates both through its own sales network and partners, as well as an online channel.

This organization, prior to the verification of the model structure developed by the author, already had its first experiences in the robotic process automation field an external vendor developed robots for this entity using the RPA tool considered to be among the industry's leading solutions (according to international analytics companies, such as Gartner or Forrester). The goal of that implementation was to verify whether robotic process automation actually met the expectations of business units and whether no technology constraints that could be a barrier for applying robotic process automation on a broader scale, existed.

Following the positive results of the first works, the company's management board made the decision to expand robotic process automation activities. It was decided that these were to be of long term nature and not a short term undertaking. In particular, this meant that substantial funds would be allocated to the project, while at the same time the company's management board was keen on appropriately positioning this undertaking and treating the project as a strategic initiative.

The main stages of the verification of the robotic process automation management model structure developed by the author are presented and the results achieved are summarized below.

The person selected by the company's management board to perform the role of the robotic process automation implementation leader took part in a series of working sessions conducted by the author, aimed at developing an initial version of the robotic process automation management model based on the proposed structure of its description. During the first session general assumptions of the robotic process automation management model were presented, definitions of the key concepts (e.g. software robot, business process, RPA platform) applicable in this undertaking were developed, elements of the model's structure were discussed, (anonymized) examples of fragments of other robotic process automation management models were 
presented, and the initial version of the robotic automation goals for that organization was defined. During the second session the entire robotic process automation management model was developed based on the structure proposed by the author. During the last session the final version of the model was prepared.

Completion of the initial verification of the robotic process automation management model structure, described in this section, allowed the author to formulate the following observations:

- the proposed model structure ensured a focus of discussions during working sessions on the robotic process automation management aspects, and not technological ones (during the workshops a very strong interest in tools related aspects of robotic automation was visible among the audience);

- it was necessary to conduct a number of conversations so that some persons participating in the working sessions could accept the need for a broader, long term view of robotic process automation, and not only an approach based on 'ad-hoc robot development';

- introduction of aspects related to communications and interaction with the external environment into the model structure constituted the basis for expanding the discussion on robotic automation beyond the units directly involved therein;

- the session participants responded positively to the way the author proposed to visualize the robotic process automation management model;

- the session participants emphasized the value of external moderation of meetings held.

At the same time, the session participants noted that access to benchmarking data from the Polish market, e.g. on robotic process automation cost estimates, would be of great value when working on the model dedicated to the given organization. Unfortunately, the author did not have access to such data during the verification of the model structure, and a significant portion of the session was also taken up by a discussion on whether and to what extent - as part of the robotic process automation model being developed - processes to be robotically automated should be indicated. The author's position was that including a list of processes to be robotically automated directly in the model was premature and might introduce unnecessary rigidity to the future studies. Some participants of the workshops emphasized, however, the practical importance of such a list. Finally, it was agreed that the model will not include an enumerative list of processes but rather an indication of the organization's business areas (as an appendix of the model), where robotic process automation will be implemented.

\section{Conclusion and future work}

In reference to the title of M. Ford's book, it can be said that we are at the beginning of the "dawn of the era of robots" (Ford, 2016). The robotic process automation changes currently underway have become the centre of attention of the newly 
forming interdisciplinary research area of 'robonomics'. It deals with advanced automation and robotic automation technologies from the point of view of their impact on economic and organizational aspects of the functioning of enterprises (Ivanov, 2017). The considerations presented in this article fit into that field.

Three objectives are outlined in the introduction to this article. Section 2 of the article accomplishes the first goal - defining the robotic process automation concept. The third part of the article discusses the key aspects of robotic process automation management - thus accomplishing the second goal. The fourth and the fifth part of the article present and describe the manner of verifying the robotic process automation management model structure, which allowed for accomplishing the third goal.

The author is planning to further expand the approach developed and presented in the article. In particular, creating a detailed procedure dealing with developing a robotic process automation management model dedicated to a specific industry, as well as collecting data and preparing a benchmark analysis enabling to determine whether and what factors impact the differentiation of planned robotic process automation management models (based, for example, on industry, company size, ownership structure) .

\section{References}

Aalst van der, W. M. P., Bichler, M., \& Heinzl, A. (2018). Robotic process automation. Business \& Information Systems Engineering, 60(4), 269-272.

Aguirre, S., \& Rodriguez, A. (2017). Automation of a Business Process Using Robotic Process Automation (RPA): A Case Study. In J. Figueroa-García, E. López-Santana, J. Villa-Ramírez, \& R. Ferro-Escobar (Eds.). Applied Computer Sciences in Engineering. WEA 2017. Communications in Computer and Information Science, (742). Cham: Springer, 65-71.

Anagoste, S. (2018). Robotic Automation Process - The operating system for the digital enterprise (Proceedings of the 12th International Conference on Business Excellence. De Gruyter Open. 12(1), pp. 54-69). Retrieved from DOI: 10.2478/picbe-2018-0007

Asatiani, A., \& Penttinen, E. J. (2016). Turning robotic process automation into commercial success Case OpusCapita. Journal of Information Technology Teaching Cases, 6(2), 67-74.

Atermia. (2018). Pokolenie $Z w$ ocenie pracodawców. Warszawa. Retrieved August 16, 2019 from https://www.aterima.hr/raport-pokolenie-z-pracodawcy

Berman, S. (2012). Digital transformation: Opportunities to create new business models. Strategy \& Leadership, 40(2), 16-24.

Clair, C., Cullen, A., \& King, M. (2017). The RPA Market Will Reach \$2.9 Billion By 2021. Forrester. Retrieved August 16, 2019 from https:/www.forrester.com/report/The+RPA+Market+Will+Reach+29+Billion+By+2021/-/E-RES137229

Fersht, P., Gupta, S., \& Christopher, E. (2019). RPA is dead. Long live integrated automation platforms. HfS Research. Retrieved August 16, 2019 from https://www.horsesforsources.com/rpadead-integrated-automation-platforms_041519

Fersht, P., \& Slaby, J. (2012). Robotic automation emerges as a threat to traditional low-cost outsourcing. HfS Research. Retrieved August 16, 2019 from https:/www.horsesforsources.com/wp-content/ uploads/2016/06/RS-1210_Robotic-automation-emerges-as-a-threat-060516.pdf 
Ford, M. (2016). Rise of the robots: Technology and the threat of a jobless future. Basic Books.

Gartner. (2019). Robotic Process Automation Software Market Grew 63\% in 2018. Retrieved August 16, 2019 from https://www.gartner.com/en/newsroom/press-releases/2019-06-24-gartner-saysworldwide-robotic-process-automation-sof

Główny Urząd Statystyczny [GUS]. (n.d.). Retrieved August 18, 2019 from https://stat.gov.pl/ obszary-tematyczne/rynek-pracy/pracujacy-zatrudnieni-wynagrodzenia-koszty-pracy/

Instytut Analiz Rynku Pracy. (2018). Rynek pracy, edukacja, kompetencje. Aktualne trendy $i$ wyniki badań. Warszawa: Instytut Analiz Rynku Pracy.

Ivanov, S. (2017). Robonomics - principles, benefits, challenges, solutions. Yearbook of Varna University of Management, (10), 283-293.

Lacit, M., \& Willcocks, L. (2017). Robotic process automation and risk mitigation: The definitive guide, United Kingdom: Steve Brookes Publishing.

Lacity, M., \& Willcocks, L. (2016). Robotic Process Automation at Telefonica O2. MIS Quarterly Executive, 15(1), 21-35.

Lacity, M., \& Willcocks, L. (2018). Robotic process and cognitive automation: The next phase. United Kingdom: Steve Brookes Publishing.

Leno, V., Dumas, M., Maggi, F. M., \& La Rosa, M. (2018). Multi-Perspective process model discovery for robotic process automation (CEUR Workshop Proceedings, pp. 37-45).

Leopold, H., van der Aa, H., \& Reijers H. A. (2018). Identifying candidate tasks for robotic process automation in textual process descriptions. Lecture Notes in Business Information Processing, (318), 67-81.

Mazur, Z., \& Orłowska, A. (2018). Jak zaplanować i przeprowadzić systematyczny przegląd literatury. Polskie Forum Psychologiczne, 23(2), 235-251.

Nylén, D., \& Holmström, J. (2015). Digital innovation strategy: A framework for diagnosing and improving digital product and service innovation. Business Horizons, 58(1), 57-67.

Osterwalder, A., \& Pigneur, Y. (2010). Business model generation: A handbook for visionaries, game changers, and challengers. USA: John Wiley and Sons.

Reis, J., Amorim, M., Melão, N., \& Matos, P. (2018). Digital transformation: A literature review and guidelines for future research. In Á. Rocha, H. Adeli, L.P. Reis, S. Costanzo (Eds.), Trends and advances in information systems and technologies. WorldCIST'18 2018. Advances in intelligent systems and computing, (745) (pp. 411-421). Cham: Springer.

Shaw, R. D., Holland, P. Ch., Kawalek, P., Snowdon, B., \& Warboys, B. (2007). Elements of a business process management system: Theory and practice. Business Process Management Journal, 13(1), 91-107.

Suri, V., Elia, M., \& Hillegersberg, J. van (2017). Software bots - the next frontier for shared services and functional excellence. Lecture Notes in Business Information Processing, (306), 81-94.

Willcocks, L., \& Lacity, M. (2016). Service automation: Robots and the future of work. United Kingdom: Steve Brookes Publishing.

Willcocks, L., Lacity, M., \& Craig, A. (2017). Robotic process automation: Strategic transformation lever for global business services? Journal of Information Technology Teaching Cases, 7(1), 17-28. 